\title{
Incidental discovery of multiple myeloma, presenting as an amyloid tumor with plasmacytic elements of the thoracic wall
}

\author{
OANA ŞERBAN, A. ACHIM, LAURA IRINA POANTĂ \\ "Iuliu Hațieganu" University of Medicine and Pharmacy Cluj-Napoca, Department of Internal Medicine
}

\begin{abstract}
Multiple myeloma is characterized by monoclonal proliferation of bone marrow plasma cells causing multiple bone lesions and overproduction of a monoclonal protein (M-protein) that could deposit in tissues (amyloidosis). Dissemination of the multiple myeloma outside the bone is rare.

We present a case of a 76 years old woman presenting with dry cough. Chest X-ray showed a giant tumor of the upper right lung. Contrast enhanced CT revealed a tumor that most probably originated from the structures of the thoracic wall. The transthoracic biopsy was inconclusive. The tumor was resected and the histopathological examination showed amyloid tumor of the thoracic wall with plasmacytic elements and lambda light chains deposits. A bone marrow aspiration was performed that found diffuse plasmacytic infiltrate of $20-60 \%$ and the serum proteins electrophoresis with immunofixation revealed elevated IgA and lambda light chains. The patient was diagnosed with IgA and lambda light chains multiple myeloma with consequent $\mathrm{AL}$ amyloidosis presenting as thoracic mass.
\end{abstract}

Keywords: multiple myeloma, lambda light chains, plasmacytoma, amyloidosis.

\section{INTRODUCTION}

Multiple myeloma is a clonal proliferative disorder of abnormal plasma cells that leads to infiltration of the bone marrow with malignant plasma cells, monoclonal protein presence in the blood and urine, deposition of misfolded protein in tissues and associated organ dysfunction [1]. It has an incidence of approximately $1.4 \%$ of all cancer cases and accounts of approximately $1.9 \%$ of all cancer deaths, having a 5 year survival rate of $44.9 \%$ [2]. The median age at diagnosis is 70 and approximately $37 \%$ of the patients are over the age of $75,37 \%$ under the age of 65 and $26 \%$ are between 65 and 74 years old $[1,3]$.

Patients with multiple myeloma usually present with bone pain ( $80 \%$ of the patients), unexplained anemia $(73 \%$ of the patients), renal impairment (20-40\%), hypercalcaemia, recurrent infections, spinal cord compressions, symptoms of amyloidosis and more rarely symptoms of hyperviscosity $[1,3]$. Those with monoclonal gammapathy of undetermined significance (MGUS) and asymptomatic multiple myeloma (considered premalignant stages that may or may not progress to multiple myeloma) have no symptoms [4]. Multiple myeloma usually leads to overproduction of IgG or IgA ( $80 \%$ of the patients), very rarely $\operatorname{IgM}, \operatorname{IgD}, \operatorname{IgE}$, and in $20 \%$ of cases it involves the production of light chains $(\kappa / \lambda)$ [4].
Solitary bone plasmacytoma represents $3-5 \%$ of the plasma cell malignancies, involving mainly the axial skeleton and the majority of them progresses to multiple myeloma. Extramedullary dissemination is rare $[4,5]$.

This case reports exhibits an uncommon pathway toward the final diagnosis of multiple myeloma and an uncommon way of presentation.

\section{CASE REPORT}

A 76 years old woman presented in our medical service with a persistent, irritating, dry cough, and with no history of fever, chills or hemoptysis. The onset of the symptoms was 3 weeks before presentation, after a viral upper respiratory tract infection treated with symptomatic drugs. Other complains were mild weight loss and loss of appetite. By taking the history of the patient we also discovered that, during the years, she was told by various doctors that the auscultation of her lungs was modified, without any corresponding radiological findings. From her personal medical history we recall essential hypertension stage 3.

Physical examination revealed pale skin, mild dehydration, no swollen lymph nodes, regular heart sounds without murmurs, normal blood pressure and heart rate, varicose veins of the lower legs, 
mild thoracic kyphosis; percussion and auscultation of the lungs revealed dull sounds at the upper region of the right lung with bronchial breath sounds at this level and no other pathological sounds; no tenderness caused by the palpation of the abdomen and no organomegaly. BMI $=31.11 \mathrm{~kg} / \mathrm{m}^{2}$.

We performed blood tests that revealed mild normocytic, normochromic anemia (hemoglobin $11 \mathrm{~g} / \mathrm{dl}$ ), normal white blood cells (WBC 9,155/L), normal platelets (PLT 336,000/L), increased ESR $(81 \mathrm{~mm} / \mathrm{h})$, normal total serum protein $(8 \mathrm{~g} / \mathrm{dl})$ and serum albumin $(3.5 \mathrm{~g} / \mathrm{dl})$, normal liver tests, normal renal function tests (serum creatinine $0.6 \mathrm{mg} / \mathrm{dl}$ ), normal total serum calcium $(2.26 \mathrm{mmol} / \mathrm{L})$, normal uric acid $(4.4 \mathrm{mg} / \mathrm{dl})$, normal sideremia, mildly increased lactate dehydrogenase (LDH $257 \mathrm{U} / \mathrm{L}$ ) and increased C-reactive protein (CRP $5.89 \mathrm{mg} / \mathrm{dl}$ ).

Based on the symptoms and physical exam we suspected pneumonia and we performed a chest $\mathrm{X}$-ray examination that showed a giant tumor mass in the right upper lung lobe with destruction of the third rib (Figure 1).

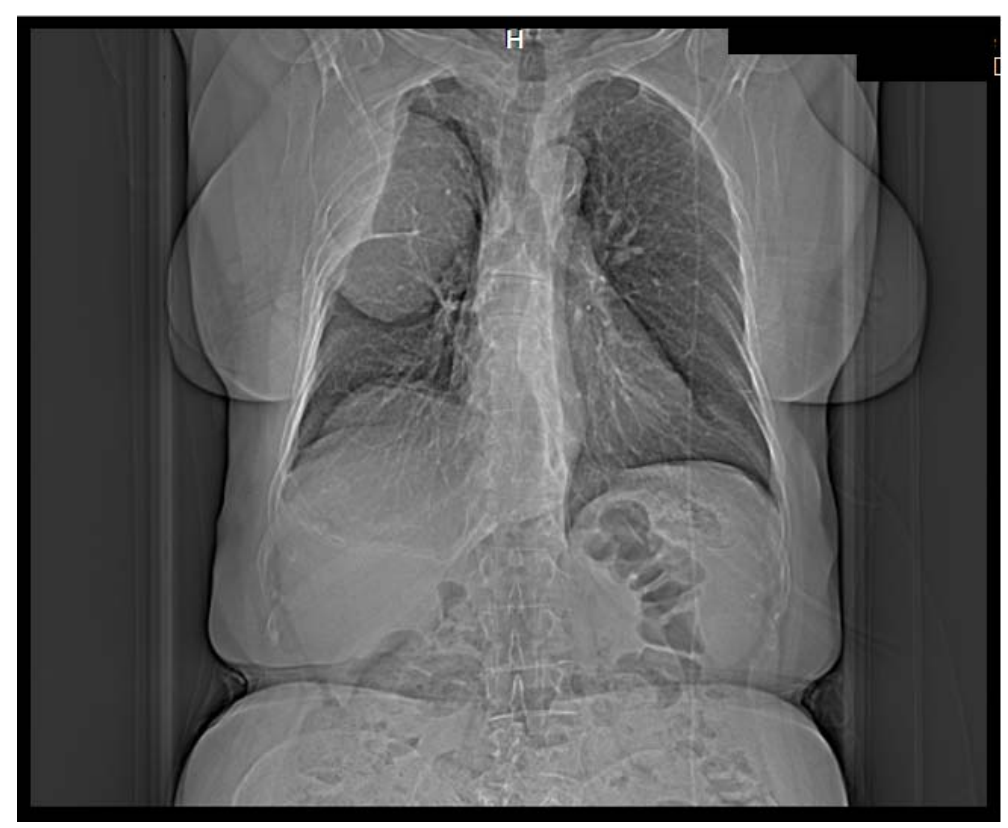

Figure 1. Chest X-ray showing a tumor of the upper right lung lobe.

We considered necessary to pursue with a contrast-enhanced CT scan (CECT) of the thorax that revealed an inhomogeneous tumor mass (formed by parenchyma, calcifications and necrosis) which measures 100/97/120 mm. The tumor developed predominantly toward the upper zone of the right lung, invaded the third rib from the scapular line to the mid-clavicular line (expansile lytic lesion of the third rib) and was relatively well delimited with an obtuse Bernou angle (Figure 2). In venous phase, the lesion became iodophilic, but slightly more pronounced in the upper external region, where the tumor included the third rib (Figure 3). The lung parenchyma surrounding the tumor did not appear infiltrated, the vessels and the bronchi were deviated by compression. The scapular and axillary fat adjacent to the tumor did not appear infiltrated and the subjacent and superjacent ribs were pushed but not invaded by the tumor. There were millimetric bilateral axillary lymph nodes and aortopulmonary window lymph nodes that measured less than $10 \mathrm{~mm}$. No pleural or pericardial effusions were present. No other modifications of the abdominal organs were visible. We concluded that we were facing a tumor which originated most probably from the structures of the right thoracic wall, the pleural origin of the tumor could not be excluded based on the CT scan.

Considering that the tumor was of parietal origin, thus the puncture of the mass being possible, we decided to perform a transthoracic needle biopsy (Tru Cut 16G). The histopathological examination revealed that the tissue sample consists of connective tissue, degenerated muscle fibers, moderate lymphocytic and histiocytic inflammatory infiltrate and several multinucleated giant cells (positive for CD 68, negative fordesmin-meaning histiocytic origin). Histology was not conclusive. 


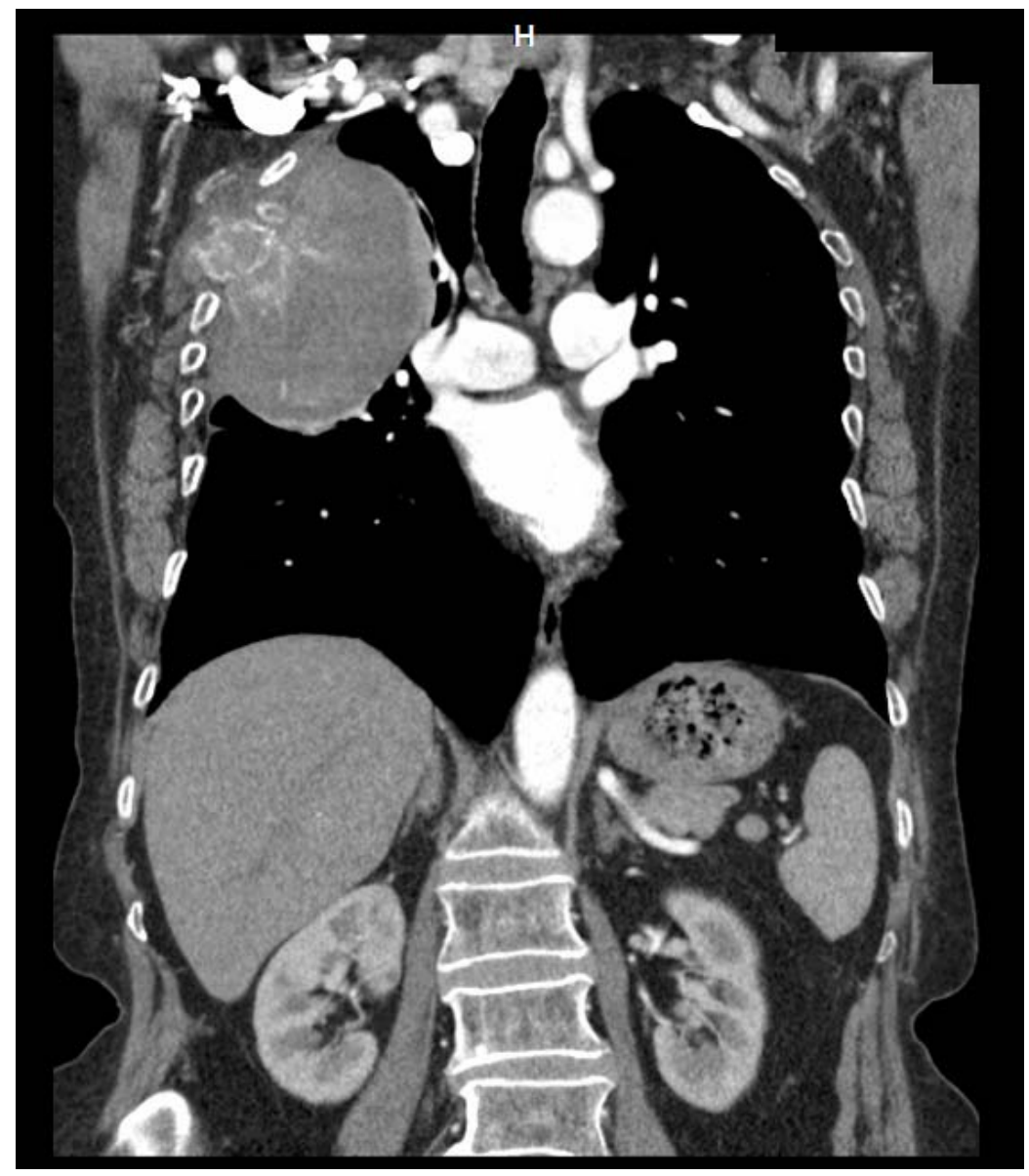

Figure 2. CECT coronal section.

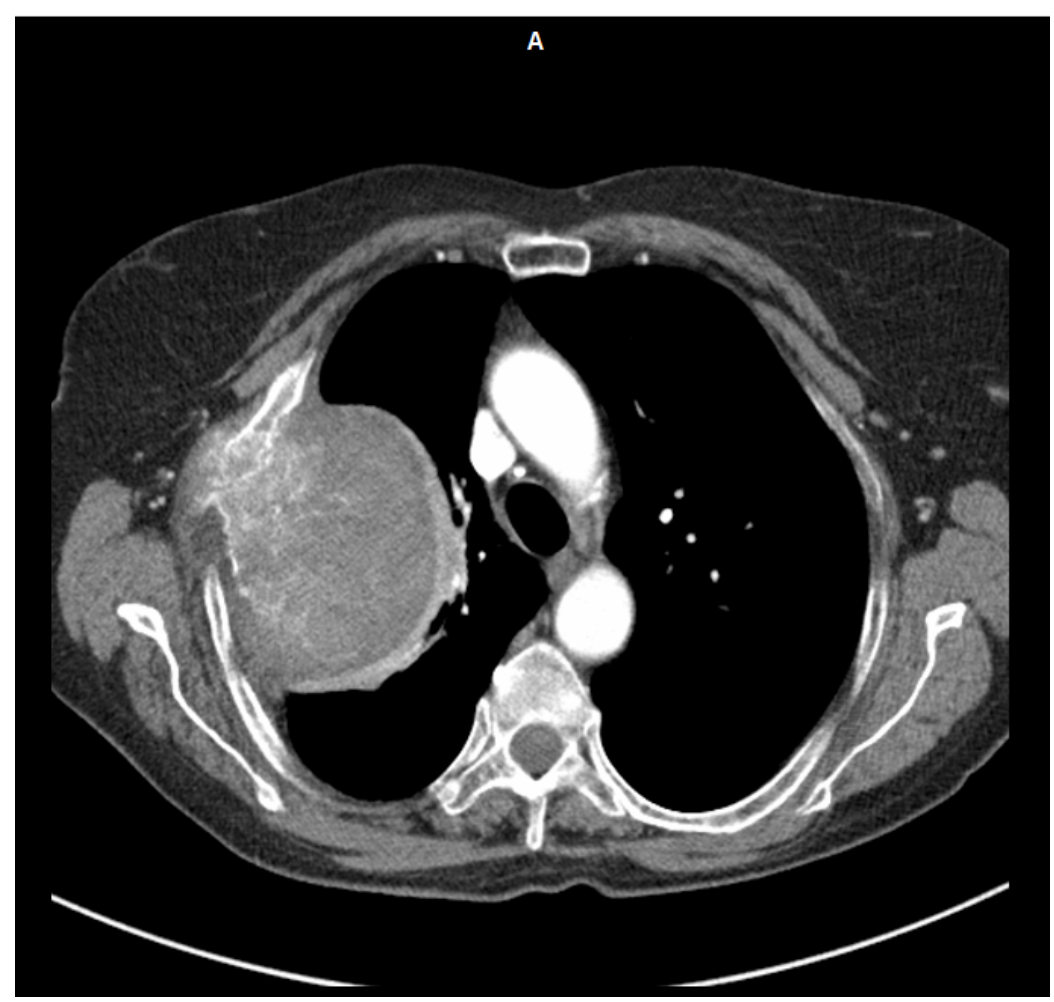

Figure 3. CECT transverse section in venous phase. 
The patient was referred to the surgery department in order to remove the tumor. The surgeon decided to perform the intervention with curative intent. The right thoracic wall was removed from the second rib to the fourth rib and superior lobectomy of the right lung was performed, followed by the reconstruction of the thoracic wall with Goretexpatch. The surgical resection specimen was sent to pathology department for histopathological assessment.

Macroscopically, the histopathological examination showed right lung lobe tissue of 15/8/4 cm with the basal pleura irregularly thickened and presenting thread-like extensions. It was connected by a tissue bridge with a mass of $12 / 4 / 2 \mathrm{~cm}$ which had a partly gray and a partly gray-reddish cut surface. Separately, there was an irregular rib resection specimen of 10/11/3 cm with accessory muscles and a ragged appearance. In addition to these two specimens, there were numerous pieces of tissue with irregular margins, grey-reddish color, which measured up to $11 / 9 / 2.5 \mathrm{~cm}$, that contained some small bone surfaces inside. The pulmonary parenchyma surface did not appear modified.

The microscopy revealed that the sections of the thoracic wall were mainly represented by pleural tissue and periosteum, which were intensely thickened. They included large acellular surfaces made of fibrillar eosinophilic material, which intensely reacted to Congo red staining and in polarized light exhibited an intense green auto-fluorescence. Therefore, it was identified as being of amyloid nature. Analyzing the marginal sections of the eosinophilic material, multinucleated giant cells could be seen, which appeared to be of multinucleated foreign body cells type, as well as outstanding partially atypical plasmacytes conglomerates of different thicknesses. These cells exhibited round-oval nuclei, which were recognized by the chromatin with a "spoked-wheel" appearance and the irregularly delimitated basophilic cytoplasm, frequently presenting a perinuclear hypochromia. The plasma cell aggregates were partially distinguished in narrow strips in the medullary spaces of the decalcificated rib fragments, where they could be found solitary between the hematopoietic cells, but more often aggregated into large conglomerates.

Immunomorphologically, the plasma cells showed the expression of CD138 (marker of plasma cells) and also the expression of monotypic lambda light chains. They were negative for CD20 and Cyclin D-1 (positive in different types of lymphomas and leukemia). The ribs were completely included in the amyloid material of the tumor, presenting a massive destruction, the cortical bone being barely recognized. The resected upper lung lobe had no neoplastic modifications, and revealed, besides the emphysematous modifications, some large deposits of anthracotic pigment and focal signs of bronchitis and bronchiolitis. The pleura was thickened, with amyloid deposits.

The morphopathological diagnosis was: extended amyloid tumor of the thoracic wall with plasmacytic myeloma elements (lambda light chains restricted).

A bone marrow aspiration was performed, and the smear examination revealed areas of fat tissue alternating with areas of blood with high cellularity and irregular diffuse plasmacytic infiltrate (20-50\% of the nucleated elements). The myeloid series were present, erythrocytic series were normoblastic, granulocytic series showed elements in all stages of differentiation, megakaryocytic series were present. The conclusion of bone marrow aspiration was: significant plasmacytic infiltrate, most likely multiple myeloma.

In order to support the diagnosis of multiple myeloma, further laboratory investigations were conducted. The serum proteins electrophoresis and immunofixation found elevated immunoglobulin A (IgA) - $1511.51 \mathrm{mg} / \mathrm{dl}$ - and lambda light chains were present.

The patient was diagnosed with IgAand lambda light chains multiple myeloma with extramedullary dissemination presenting as pulmonary mass and AL amyloidosis. The patient was referred to the hematology department for further management and melphalan - zolendronic acid chemotherapy regimen was initiated.

\section{DISCUSSION}

Plasma cell neoplasms represent diseases characterized by the abnormal proliferation of plasma cells forming tumors in the bones or other tissues of the body. There are several entities included in the group of plasma cell proliferative disorders, some of them presenting as localized disorder like plasmacytomas, and some of them with systemic involvement like multiple myeloma (MM) [6].

Plasmacytomas are rare malignant tumors of the plasma cells which develop within the bone or within soft tissues. They are classified in three groups: solitary bone plasmacytomas (SBP - one 
single tumor localized in the bone), solitary extramedullary plasmacytomas (SEP - one single tumor localized outside bone, in soft tissues) and multiple solitary plasmacytomas (MSP). Solitary bone plasmacytomas and extramedullary plasmacytomas may be early stages of multiple myeloma as the majority of them progress to multiple myeloma within years $[5,7]$.

Multiple myeloma is the most common plasma cell neoplasm, and the second most frequent blood cancer. It is a systemic disorder, a proliferation of abnormal plasma cells that accumulate in the bone marrow and also form multiple plasmacytomas in many bones of the body. Multiple myeloma (symptomatic myeloma) is usually preceded by a premalignant stage called monoclonal gammopathies of undetermined significance (MGUS), and has an early stage of asymptomatic myeloma. These two entities could remain stable or could progress to symptomatic myeloma. There is also a very rare form of myeloma which does not secrete paraprotein (non-secretory myeloma) $[4,8]$.

The main characteristic that most of the monoclonal gammopathies have in common is the overproduction of a monoclonal protein (M protein) an abnormal immunoglobulin (IgG, IgA, $\operatorname{IgM}, \operatorname{IgD}$ and IgE). Each immunoglobulin molecule is formed by two heavy chains $(\mathrm{H})$ and two light chains $(L-\kappa$ or $\lambda)$. The misfolded immunoglobulin light chains fragments (amyloid) accumulate in the extracellular space of the body leading to multiple organ failure (kidney, heart, liver, peripheral nervous system). The resulting disorder is named immunoglobulin light chain amyloidosis (AL amyloidosis) $[4,9]$. Recently, AL amyloidosis was considered a symptomatic myeloma-defining condition [9]. AL amyloidosis can be systemic or rarely localized (when the organ involvement and the monoclonal protein in serum or urine are absent, and it is determined by a focal infiltrate of clonal plasma cells within the same tissue as the amyloid deposits) [9].

The criteria for diagnosis of multiple myeloma are the presence of clonal plasma cells in the bone marrow of $\geq 10 \%$ (our patient had 20 $50 \%$ ) or bony or extramedullar plasmacytoma proven by a biopsy also demonstrating the presence of $\kappa / \lambda$ light-chains (our patient had plasmacytoma of the rib with $\lambda$ light-chains) and any one or more of the following myeloma defining events: evidence of end organ damage (hypercalcemia, renal insufficiency, anemia with a hemoglobin value of $>$ $2 \mathrm{~g} / \mathrm{L}$ below the lower limit of normal or a hemoglobin value $<10 \mathrm{~g} / \mathrm{L}$, osteolytic lesions - our patient had anemia but hemoglobin was $11 \mathrm{~g} / \mathrm{dl}$ ) or any one or more of the following malignancy biomarkers (clonal plasma cell in the bone marrow $\geq$ $60 \%$, involved/uninvolved serum free light chain ratio $\geq 100,>1$ focal lesions on MRI studies) [4].

The solitary bone plasmacytoma is defined as a solitary lesion of bone (biopsy-proven with evidence of clonal plasma cells) with normal bone marrow, normal skeletal survey (except for the primary solitary lesion) and absence of end-organ damage [4].

Since some of the cases of solitary bone plasmacytoma may contain a few plasma cells in the bone marrow, another entity called solitary plasmacytoma with minimal marrow involvement was defined. The solitary bone plasmacytoma with minimal marrow involvement has the same characteristics as solitary bone plasmacytoma, except for the fact that the bone marrow may contain clonal plasma cells $<10 \%$ [4].

Our patient had one single bone lesion (biopsy-proven with evidence of clonality) with clonal bone marrow plasma cells $\geq 10 \%$ and as respects the evidence of end-organ damage, she had normal serum calcium, normal renal function, normal skeletal survey and mild anemia but with a hemoglobin $>10 \mathrm{~g} / \mathrm{dl}$. Also she had an elevated IgA level with serum lambda light-chains and evidence of AL amyloidosis (positive amyloid staining by Congo red, evidence that amyloid is light-chainrelated established by direct examination of the amyloid using polarized light and the presence of a monoclonal plasma cell proliferative disorder, but without any amyloid-related systemic syndrome renal, liver, heart, gastrointestinal tract or peripheral nerve involvement).

Considering the data collected during the diagnostic process, we can extract the particularities of this case as being lack of symptoms other than those given by the rib tumor (cough - nonspecific for multiple myeloma), lack of evidence of end organ damage (hemoglobin $>10 \mathrm{~g} / \mathrm{dl}$ ) and the absence of bone lesions other than the rib tumor. A possible explanation could be that the patient had for years a primary solitary rib plasmacytoma (considering the long history of modified auscultation of the lung even if there was no radiological evidence of the tumor, and considering the size of the tumor) that is currently progressing to multiple myeloma, progressively developing the criteria for multiple myeloma (as the patient does not completely satisfy the criteria) and this process was not 
complete at the time of diagnosis. Another explanation could be that the plasmacytoma was simply a consequence of multiple myeloma.

It is important to distinguish between solitary plasmacytoma and multiple myeloma as long as the management of the disorders is different. In case of solitary plasmacytoma radical radiotherapy is the treatment of choice [5] and in case of multiple myeloma a chemotherapy regimen should be considered [10]. Also, when a plasmacytoma is found, further investigations should be performed to search for a possible multiple myeloma.

Mielomul multiplu este caracterizat prin proliferarea monoclonală a plasmocitelor din măduvă determinând numeroase leziuni osoase şi hiperproducția unei proteine monoclonale (proteina $M$ ), ce se poate depune în țesuturi (amiloidoza). Diseminarea mielomului multiplu în afara sistemului osos e rară.

Prezentăm cazul unei femei de 76 de ani care s-a prezentat cu tuse seacă. Radiografia pulmonară a arătat o tumoră gigantă la nivelul plămânului drept superior. Tomografia computerizată cu substanță de contrast a confirmat prezența tumorii, cu origine mai probabilă din peretele toracic. Biopsia transtoracică a fost neconcludentă. Tumora a fost rezecată, iar examinarea histopatologică a arătat o masă de amiloid a peretelui toracic, cu elemente plasmocitare şi depozite de lanțuri uşoare lambda. Aspiratul medular realizat a arătat infiltrat difuz plasmocitar, 20-60\%, precum şi IgA şi lanțuri uşoare lambda la imunelectroforeza proteinelor serice cu imunofixare. Pacienta a fost diagnosticată cu mielom multiplu cu IgA şi lanțuri uşoare lambda cu amiloidoză secundară $A L$, manifestată ca o masă toracică.

Correspondence to: Laura Irina Poantă, "Iuliu Hațieganu” University of Medicine and Pharmacy, Cluj-Napoca Email: laurapoanta@yahoo.com, mobile: 0755146850

\section{REFERENCES}

1. PALUMBO A, ANDERSON K. Multiple Myeloma. N Eng J Med. 2011; 364(11):1046-60.

2. HOWLADER N, NOONE AM, KRAPCHO M, GARSHELL J, MILLER D, ALTEKRUSE SF, et al. (eds) SEER Cancer Statistics Review, 1975-2011, National Cancer Institute Bethesda, MD, http://seercancergov/csr/1975_2011/, based on November 2013 SEER data submission, posted to the SEER web site, April 2014.

3. KING AJ, GOODING S, RAMASAMY K. Managing multiple myeloma in the over 70s: A review. Maturitas. 2015; 80(2):148-54.

4. RAJKUMAR SV, DIMOPOULOS MA, PALUMBO A, BLADE J, MERLINI G, MATEOS MV, et al. International Myeloma Working Group updated criteria for the diagnosis of multiple myeloma. Lancet Oncol. 2014; 15(12):e538-48.

5. HUGHES M, SOUTAR R, LUCRAFT H, OWEN R, BIRD J. Guidelines on the diagnosis and management of solitary plasmacytoma of bone, extramedullary plasmacytoma and multiple solitary plasmacytomas: 2009 update 2009. Available from: http://www.bcshguidelines.com/documents/solitary_plamacytoma_bcsh_FINAL_190109.pdf.

6. SOUTAR R, LUCRAFT H, JACKSON G, REECE A, BIRD J, LOW E, et al. Guidelines on the diagnosis and management of solitary plasmacytoma of bone and solitary extramedullary plasmacytoma. Br J Haematol. 2004; 124(6):717-26.

7. KILCIKSIZ S, KARAKOYUN-CELIK O, AGAOGLU FY, HAYDAROGLU A. A review for solitary plasmacytoma of bone and extramedullary plasmacytoma. Scientific World Journal. 2012; 2012:895765.

8. INTERNATIONAL MYELOMA WORKING GROUP. Criteria for the classification of monoclonal gammopathies, multiple myeloma and related disorders: a report of the International Myeloma Working Group. Br J Haematol. 2003; 121(5):749-57.

9. GILLMORE JD, WECHALEKAR A, BIRD J, CAVENAGH J, HAWKINS S, KAZMI M, et al. Guidelines on the diagnosis and investigation of AL amyloidosis. Br J Haematol. 2015; 168(2):207-18.

10. BIRD JM, OWEN RG, D'SA S, SNOWDEN JA, PRATT G, ASHCROFT J, et al. Guidelines for the diagnosis and management of multiple myeloma 2011. Br J Haematol. 2011; 154(1):32-75.

Received February 25, 2015 